\title{
Field Research of Tourism Supply and Demand in Mountain Villages: The Case of West Rhodopes Architecture Reserves
}

\author{
Dă̆ Köylerinde Turizmde Arz ve Talep Alan Araştırması: \\ Batı Rodoplar Mimari Rezervleri Örneği
}

EIka DOGRAMADJIEVA

Geography of Tourism Department, Sofia University "St. Kliment Ohridsky”, Sofia, Bulgaria

\begin{abstract}
The current paper presents results of a questionnaire-based survey of local tourism entrepreneurs in three villages in the West Rhodope Mountain. The survey was carried out within a wider project aimed on adaptation of previously existing models of studying local tourism development and management to small mountain destinations. Comparative analysis of the three villages outlines the features of their contemporary tourism supply and demand, including the variety of services offered and marketing instruments used as well as the visitors' profile and behavior, the seasonality of demand and the corresponding problems regarding utilization of accommodation facilities. Special emphasis is put on the investments made by the entrepreneurs in individual product development over the last 5 years and on the respondents' vision of their business priorities in the future. The results show what type of information could be collected and analyzed based on the suggested methodology, in order to overcome the existing deficit of information about tourism development in small mountain destinations that often do not even fall into the scope of the official statistics. Conclusions are drawn regarding the advantages and disadvantages of the suggested methodology and its application in future tourism surveys.
\end{abstract}

Key words: Mountain villages, tourism supply and demand, questionnaire survey, local business.

Özet: Bu makale Batı Rodop Dağı'nın üç köyünde yerel turizm girişimcileriyle yapılmış anket tabanlı bir araştırmanın sonuçlarını göstermektedir. Anket, küçük dağ destinasyonlarında yerel turizm yönetimi ve geliştirilmesi çalışmalarının varolan modellerinin uyarlamasını amaçlayan daha geniş kapsamlı bir proje çerçevesinde gerçekleştirilmiştir. Üç köyün karşılaştırmalı analizi, konaklama tesislerinin kullanımına ilişkin sorunlar ve talebin mevsimselliği, ziyaretçilerin profil ve davranışlarının yanı sıra, sunulan hizmetlerin çeşitliliği ve pazarlama araçlarını içeren çağdaş turizmin arz ve talep özelliklerini özetlemektedir. Son beş yılda bireysel ürün geliştiren girişimciler tarafından yapılan yatırımlara ve ankete cevap verenlerin gelecekteki iş öncelikleri vizyonuna özel vurgu yapılmaktadır. Sonuçlar önerilen yönteme bağlı olarak sıklıkla resmi istatistiklerin kapsamı içine girmeyen küçük dağ destinasyonlarındaki turizm gelişimi konusundaki bilgi açığının üstesinden gelmek için toplanabilir ve analiz edilebilir türden bilgileri göstermektedir. Önerilen yöntem ve onun uygulamalarının gelecekteki turizm araştırmalarındaki avantaj ve dezavantajları bakımından sonuçlar çıkarılmıştır.

Anahtar sözcükler: Dağ köyleri, turizm arz ve talebi, anket araştırması, yerel iş. 


\section{Introduction}

The lack of detailed, reliable and up-to-date information about tourism development at local level has been widely recognized as a problem in terms of tourism planning and destination management. It has been discussed in a number of academic publications over the last decades (Gunn, 1988; Inskeep, 1991; Middleton and Hawkins, 1998; Marinov et al., 2000; Evrev et al., 2003; Marinov, 2004; Marinov et al., 2009; Assenova, 2010). In Bulgaria serious deficits in the official statistical data emerged after the collapse of the communist system. Despite the considerable progress that has been achieved in tourism statistics over the last few years, it still does not meet the current needs, especially at local level. Moreover, the importance of information in decision-making process is often underestimated, while the local capacity for regular data collection, processing and analysis is quite limited. The problem is most evident in small mountain destinations that often do not even fall into the scope of the official tourism statistics. Typically, the level of tourism development there is low while the structure of supply is highly fragmented and dominated by small businesses. On the other hand, tourism is usually declared a priority sector in such socially and economically underprivileged areas, and it is anticipated to utilize their diverse potential, to stimulate sustainable development and to balance regional differences.

To overcome the existing information deficit a number of empirical tourism studies have been carried out by the Tourism Department at Sofia University over the last 10-15 years in different resorts and municipalities throughout the country (Marinov et al., 2000; Vodenska, 2001; Dogramadjieva, 2003; Vodenska, 2005; Popova et al., 2005; Assenova, 2009). Their results have supported tourism policy-making and have provided sound groundwork for further analysis and theoretical generalization. The methodology of such studies has been significantly refined on the ground of the gained experience. However, there is always space for further improvement with the reference to both the efficiency of research process and the reliability of results.

The research presented in this paper was carried out in 2011 within a wider project aimed on adaptation of previous models of studying local tourism development and management to small mountain destinations. The adapted model was tested through field research and comparative analysis of three villages in the West Rhodope Mountain. The field research comprised of two main components:

\section{$\checkmark$ Questionnaire-based survey of local tourism entrepreneurs}

$\checkmark$ Personal interviews with the key actors in local tourism development

This paper is focused on the first component of the field research - the questionnaire based survey and its main results ${ }^{*}$. The presented comparative analysis of the three villages outlines the features of their contemporary tourism supply and demand, including the variety of services offered and marketing instruments used as well as the visitors' profile and behavior, the seasonality of demand and the corresponding problems regarding utilization of accommodation facilities. Special emphasis is put on the investments made by entrepreneurs in individual product development over the last 5 years and on the respondents' vision of their business priorities in the future.

\section{The Research Territorial Scope and Methodology}

The survey was conducted in the villages of Dolen, Lesten and Kovachevica that are located in the West Rhodope Mountain, just 25-40 km away from the nearest border check point with the Republic of Greece. The proximity of the area to the Greek border and its limited accessibility from the capital city of Sofia had put it in social and economic isolation for a long time in the past decades. However, recently the three villages have obtained new perspectives evolving from the EU accession of Bulgaria, the improvement of cross-border transport infrastructure along the Mesta River as well as the development of several significant mountain and SPA resorts in the region.

\footnotetext{
* The second component of the field research is presented in another publication (Marinov, 2012).
} 


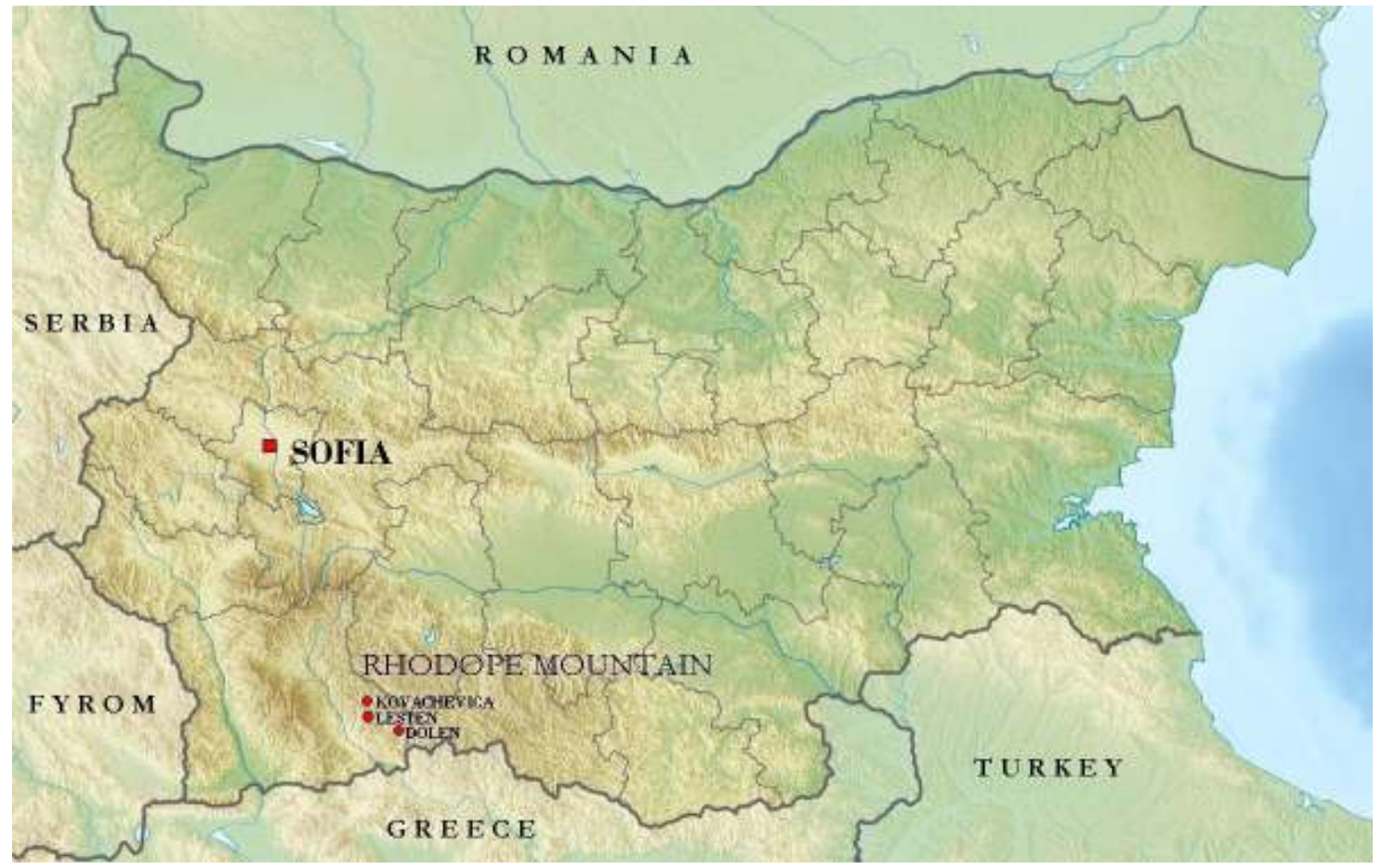

Figure 1. Location map of the studied area

The villages of Dolen, Lesten and Kovachevica are known as sites of preserved traditional architecture and beautiful nature. Their specific appearance and atmosphere have been commercialized by the development of small tourism businesses since the mid 1990s. The three villages are characterized by regional identity and growing popularity as tourist destinations offering a combination of heritage, rural and ecotourism. Yet, despite the existing general perception of their successful tourism development, no resolute research has been carried out there before.

The survey of local entrepreneurs was conducted in August 2011. It was based on specially designed questionnaire that comprised of 30 questions (5 open and 25 close-ended). To some of the close-ended questions a possibility to add information and free comments was provided. Interviewercompletion approach was applied in the survey that ensured fuller and more accurate answers but proved to be time-consuming and highly dependent on interviewers' experience and motivation. Practically all local entrepreneurs were interviewed -29 respondents in total, i.e. 11 in Kovachevica, 2 in Lesten and 16 in Dolen. Obtained quantitative and qualitative information was processed and analyzed in order to outline the current features of tourism supply and demand in the three villages as well as to delineate their common problems and important distinctions ${ }^{*}$. The results show what type of information could be collected and analyzed based on the suggested methodology.

\section{Research Findings}

\subsection{Main features of accommodation supply}

According to the survey results the total accommodation capacity of the studied area amounts to 320 bed places spread in 29 accommodation units. All three villages are very small tourism destinations: Kovachevica offers 129 bed places, Dolen - 119 and Lesten - 72 (Table 1). The average

\footnotetext{
* Different models of rural tourism development have been identified, based on the outlined distinctions (Assenova, 2012)
} 
capacity of the accommodation establishments is small everywhere but most of all in Dolen ( 7 beds per unit), followed by Kovachevica (12 beds per unit) and Lesten ( 36 beds per unit).

\begin{tabular}{|c|c|c|c|c|c|}
\hline & \multicolumn{2}{|c|}{ Accommodation units } & \multicolumn{2}{|c|}{ Available bed places } & \multirow{2}{*}{$\begin{array}{l}\text { Average } \\
\text { capacity }\end{array}$} \\
\hline & Number & $\%$ & Number & $\%$ & \\
\hline Lesten & 2 & $7 \%$ & 72 & $23 \%$ & 36 \\
\hline Kovachevica & 11 & $38 \%$ & 129 & $40 \%$ & 12 \\
\hline Dolen & 16 & $55 \%$ & 119 & $37 \%$ & 7 \\
\hline Total & 29 & $100 \%$ & 320 & $100 \%$ & 11 \\
\hline
\end{tabular}

The structure of supply is dominated by guest houses but the models of the facilities management and of tourist service are different. In Kovachevica most of the accommodation units are run by the owners who are directly involved in servicing. Typical of Dolen is renting of the whole house without hosts. Most of the houses there are managed by three local residents who welcome and accommodate tourists. In Lesten there is one holiday village comprising of 15 houses run as a collective accommodation establishment and one small hotel. The both units operate as commercial companies and the employees are not residents of the village.

The type of accommodation determines the fragmented tourism business in the studied area (Table 2). Nearly $90 \%$ of the accommodation units in Dolen and almost $2 / 3$ of them in Kovachevica offer less than 10 beds. Not a single establishment in Dolen has more than 20 beds and in Kovachevica there is only one relatively bigger establishment. The situation in Lesten is a bit different as the total capacity of the holiday village comes up to 60 bed places, while the hotel is very small ( 12 beds). Such a structure of supply premises small-scale tourism development based on authentic atmosphere and individual guest servicing. However, it determines the limited possibility of the establishments to meet organized tourist groups (respectively to rely on „certain” tourist demand) as well as the difficult achievement of consensus among separate entrepreneurs on the topics of common interest.

Table 2. Structure of accommodation facilities by size

\begin{tabular}{|l|c|c|c|c|c|c|c|c|}
\hline \multirow{2}{*}{} & \multicolumn{4}{|c|}{ Number of establishments } & \multicolumn{4}{c|}{ Share of establishments } \\
\cline { 2 - 9 } & $<10$ beds & $11-20$ beds & $>21$ beds & Total & $<10$ beds & $11-20$ beds & $>21$ beds & Total \\
\hline Lesten & 0 & 1 & 1 & 2 & $0 \%$ & $50 \%$ & $50 \%$ & $100 \%$ \\
\hline Kovachevica & 7 & 3 & 1 & 11 & $64 \%$ & $27 \%$ & $9 \%$ & $100 \%$ \\
\hline Dolen & 14 & 2 & 0 & 16 & $88 \%$ & $13 \%$ & $0 \%$ & $100 \%$ \\
\hline Total & 21 & 6 & 2 & 29 & $72 \%$ & $21 \%$ & $7 \%$ & $100 \%$ \\
\hline
\end{tabular}

The greatest majority of accommodation facilities are open for tourists throughout the year ( $90 \%$ of the establishments and $93 \%$ of the available bed places). Only in Kovachevica 3 houses operate seasonally composing $27 \%$ of the accommodation units and $19 \%$ of all beds in the village. Low seasonality of supply makes it possible to develop all year round tourism but on the other hand it determines the problematic utilization of the existing bed capacity.

In general, offered accommodation facilities are new. Most of the establishments were open in the last 5 years $(62 \%)$ while more than $40 \%$ of them were open in the last $1-2$ years (Figure 2). Few 
businesses (in Kovachevica and Lesten) have been operating since the mid 1990s and can benefit from longer experience and greater popularity.

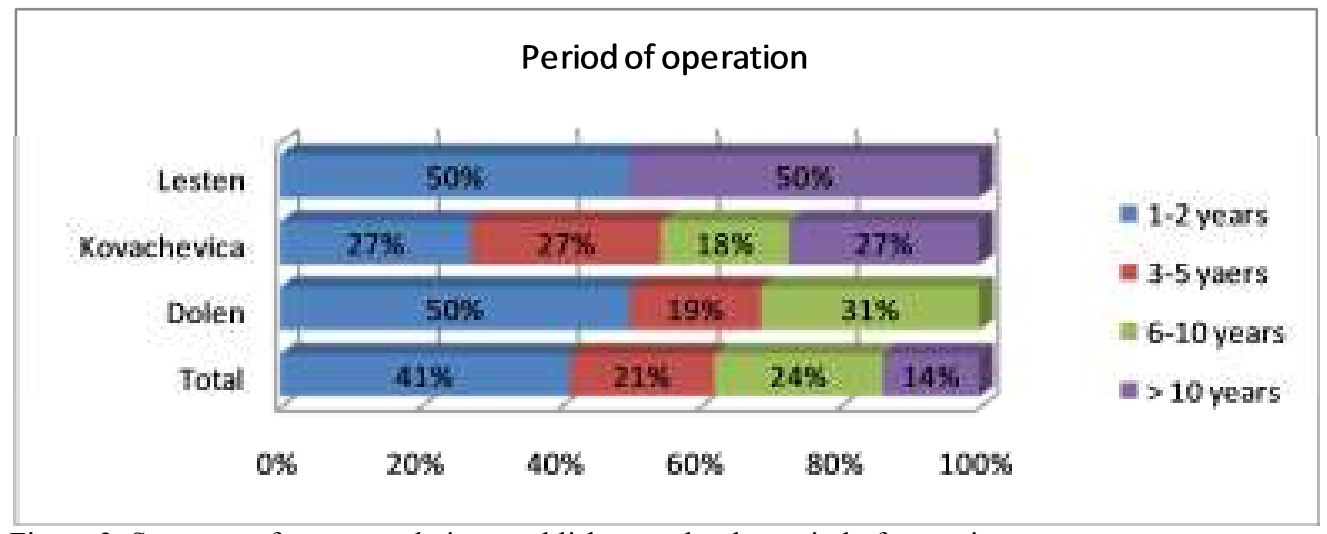

Figure 2. Structure of accommodation establishments by the period of operation

An important feature as well as a serious problem of the existing supply is that many accommodation facilities are of illegal status. This is valid for all of the villages but is most prominent in Dolen where $94 \%$ of the establishments with $90 \%$ of the available bed places are not categorized (Figure 3). According to the respondents, the reasons for the high share of uncategorized supply are the expensive taxes and the complicated administrative procedures for categorization but it is also obvious that the local authorities underestimate the problem and do not put special efforts on its resolution. Most of the entrepreneurs operate as private persons and their receipts from tourism are considered as additional income. The highest share of private persons is observed in Dolen (88\%) while the greatest diversity of merchants is typical for Kovachevica (private persons $-45 \%$; natural person merchants $-27 \%$; limited liability companies $-27 \%$ ). Only in Lesten all two accommodation establishments operate as commercial companies.

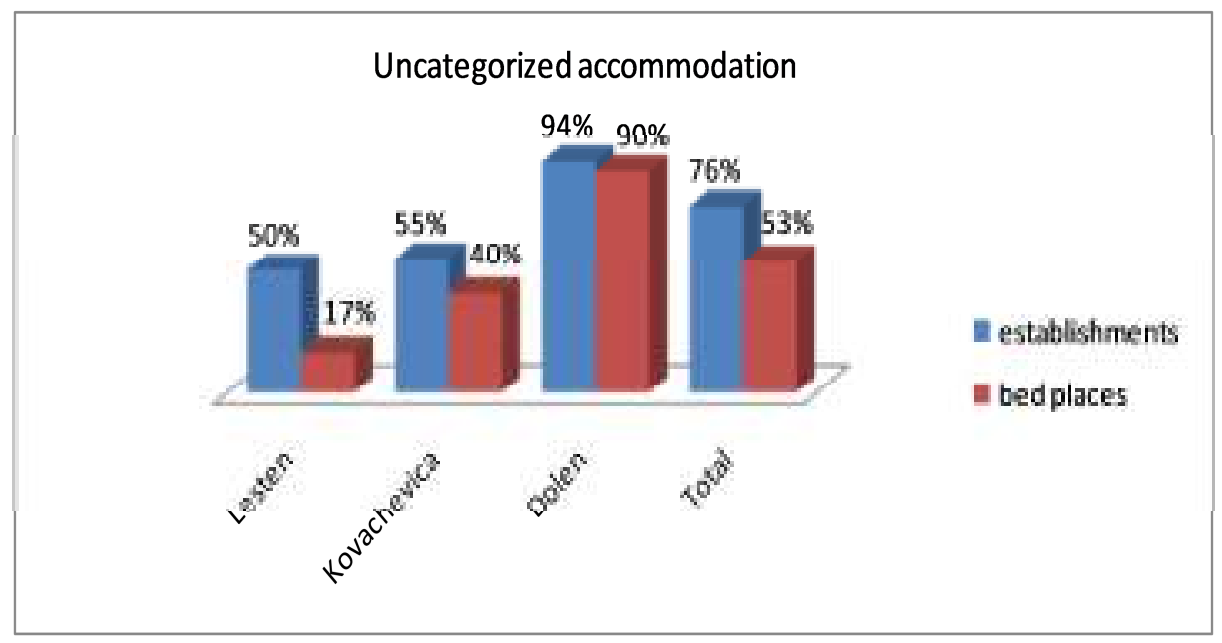

Figure 3. Share of uncategorized accommodation establishments and bed places

Most establishments offer more than just accommodation but the amenities and supplementary services are limited in variety (Table 3 ). The greatest average number of supplementary services is provided in Lesten $(6,5$ per accommodation unit), followed by Kovachevica $(5,1)$ and Dolen $(4,1)$. Guided tours, food and beverage facilities, folklore and culinary attractions are much better developed in Lesten and Kovachevica while amenities for self-cooking are typical of Dolen. Few accommodation 
establishments provide parking places which is a serious problem in Kovachevica and Dolen. There are almost no possibilities to buy souvenirs in Lesten and Dolen. Few entrepreneurs (only in Kovachevica) offer technical equipment for seminars and meetings. The availability of swimming pools, fitness or other sport facilities is rather an exception in all of the villages. SPA and wellness services are not developed at all.

Table 3. Supplementary services and facilities offered by accommodation establishments - \% of establishments and average number of services offered per unit

\begin{tabular}{|c|c|c|c|c|}
\hline & Lesten & Kovachevica & Dolen & Total \\
\hline Guided tours & $50 \%$ & $64 \%$ & $100 \%$ & $83 \%$ \\
\hline Amenities for self cooking & $50 \%$ & $45 \%$ & $94 \%$ & $72 \%$ \\
\hline Information about local sites & $0 \%$ & $64 \%$ & $75 \%$ & $66 \%$ \\
\hline Internet access & $100 \%$ & $45 \%$ & $50 \%$ & $52 \%$ \\
\hline Food and beverage facilities & $100 \%$ & $45 \%$ & $13 \%$ & $31 \%$ \\
\hline Transport services & $50 \%$ & $36 \%$ & $25 \%$ & $31 \%$ \\
\hline Folklore and culinary attractions & $100 \%$ & $55 \%$ & $6 \%$ & $31 \%$ \\
\hline Parking place & $100 \%$ & $18 \%$ & $13 \%$ & $21 \%$ \\
\hline Souvenirs & $50 \%$ & $18 \%$ & $6 \%$ & $14 \%$ \\
\hline Sport facilities & $50 \%$ & $18 \%$ & $0 \%$ & $10 \%$ \\
\hline Equipment for seminars & $0 \%$ & $27 \%$ & $0 \%$ & $10 \%$ \\
\hline Swimming pool & $0 \%$ & $9 \%$ & $6 \%$ & $7 \%$ \\
\hline Hiring of bicycles, etc. & $0 \%$ & $18 \%$ & $0 \%$ & $7 \%$ \\
\hline Fitness facilities & $0 \%$ & $0 \%$ & $6 \%$ & $3 \%$ \\
\hline SPA and wellness services & $0 \%$ & $0 \%$ & $0 \%$ & $0 \%$ \\
\hline $\begin{array}{l}\text { Number of amenities and compimentary } \\
\text { services }\end{array}$ & 13 & 56 & 65 & 134 \\
\hline Number of accommodation establishments & 2 & 11 & 16 & 29 \\
\hline $\begin{array}{l}\text { Average number of complementary services } \\
\text { offered in accommodation establishments }\end{array}$ & 6,5 & 5,1 & 4,1 & 4,6 \\
\hline
\end{tabular}

In total $28 \%$ of the local entrepreneurs cooperate with tour operators and travel agents - just $13 \%$ of the respondents in Dolen and about half of those in Lesten and Kovachevica (Figure 4). Only bigger accommodation establishments rely on this type of collaboration. Many entrepreneurs do not believe it would help them to achieve higher occupancy but consider that high commission rates would reduce their profit. As far as intermediary tourist companies operate in the area, in Lesten there are only touroperators specialized in domestic tourism, while in Dolen - only touroperators specialized in incoming tourism (Figure 4). In Kovachevica both types of companies are presented but those specialized in incoming tourism predominate.

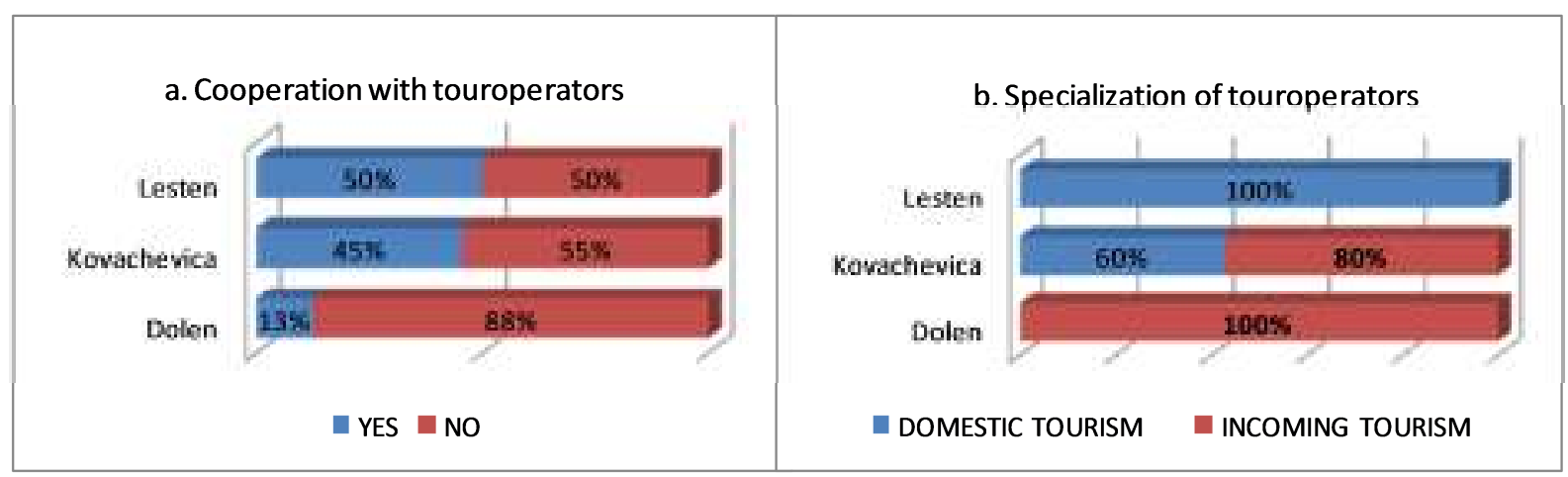

Figure 4. Cooperation with touroperators and their specialization - share of respondents 
Indisputably, Internet holds the first position among the means of advertizing used by local entrepreneurs (Table 4). Many accommodation units have their own web sites; some of them are presented for free in national tourist sites or are included in touroperators' on-line reservation systems. The use of social networks is still limited. Just one hotelier from Kovachevica is enrolled in international sites (bed\&breakfast.com and tripadvisor.com). For the time being, the number of reservations for accommodation through Internet is small. However, according to many entrepreneurs this is the most effective marketing tool and the majority of clients have learned about their product from the global network. The rest of the advertizing opportunities are not widely used. Almost half of the entrepreneurs in Kovachevica (45\%) have stated they do not advertize their establishments at all but rely on word-to-mouth information as it is the most important one. Surprisingly, such answers have not been given in Lesten and Dolen.

Table. 4. Means of advertising used by local entrepreneurs (\% of respondents)

\begin{tabular}{|l|r|r|r|r|r|r|r|r|}
\hline & Internet & $\begin{array}{c}\text { Brochures } \\
\text { \& leaflets }\end{array}$ & $\begin{array}{c}\text { Word-to- } \\
\text { mouth } \\
\text { information }\end{array}$ & $\begin{array}{c}\text { No } \\
\text { advertizing } \\
\text { at all }\end{array}$ & $\begin{array}{c}\text { Tourism } \\
\text { stock } \\
\text { markets }\end{array}$ & $\begin{array}{c}\text { Printed } \\
\text { media }\end{array}$ & $\begin{array}{c}\text { Radio / TV } \\
\text { advertizing }\end{array}$ & $\begin{array}{c}\text { Number of } \\
\text { respondents }\end{array}$ \\
\hline Lesten & $100 \%$ & $50 \%$ & $0 \%$ & $0 \%$ & $0 \%$ & $0 \%$ & $0 \%$ & 2 \\
\hline Kovachevica & $64 \%$ & $18 \%$ & $45 \%$ & $45 \%$ & $9 \%$ & $0 \%$ & $0 \%$ & 11 \\
\hline Dolen & $75 \%$ & $13 \%$ & $0 \%$ & $0 \%$ & $0 \%$ & $0 \%$ & $0 \%$ & 16 \\
\hline Total & $72 \%$ & $17 \%$ & $17 \%$ & $17 \%$ & $3 \%$ & $0 \%$ & $0 \%$ & 29 \\
\hline
\end{tabular}

The price level of offered accommodation is generally low - in most of the cases rates fall into the range of 5-15 EUR with no breakfast included. Yet, separate establishments (mainly in Kovachevica) sell their product on much higher prices - up to 100 EUR per person for full board, which illustrates the existence of "boutique" offers with very high quality of service oriented to limited market segments with higher than the average living standard.

The greatest majority of accommodation establishments offer discounts for children, longer stay and organized tourists. Rarely kids under 10 years old are accommodated for free. Almost everywhere the rates vary among seasons. However, price differentiation is not used as an instrument to attract visitors in the low seasons. On the contrary, most of the entrepreneurs raise the rates in winter to compensate the increased expenditures for heating. Survey results also indicate that the current economic crisis and the declining volume of demand over the last 2-3 years puts the local entrepreneurs in a very delicate situation as they cannot afford price rising although the operating costs are constantly increasing.

\subsection{Amount and structure of tourist demand}

In 2010 the accommodation facilities in the three villages welcomed nearly 3600 overnight visitors with 7500 nights spent. The average duration of stay in the studied area does not exceed 2,5 days and it is extremely low in Kovachevica $(1,9)$. Everywhere domestic overnight visitors stay slightly longer than foreigners (Table 5).

Table 5. Volume of tourist demand in 2010

\begin{tabular}{|l|r|r|r|r|r|r|r|r|r|}
\hline & \multicolumn{3}{|c|}{ Number of overnight visitors } & \multicolumn{3}{|c|}{ Number of nights spent } & \multicolumn{3}{|c|}{ Average duration of stay } \\
\cline { 2 - 10 } & Total & Domestic & Foreign & Total & Domestic & Foreign & Total & Domestic & Foreign \\
\hline Lesten & 845 & 806 & 39 & 2094 & 2017 & 77 & 2,5 & 2,5 & 2,0 \\
\hline Kovachevica & 2068 & 1623 & 445 & 3901 & 3109 & 792 & 1,9 & 1,9 & 1,8 \\
\hline Dolen & 669 & 620 & 49 & 1437 & 1387 & 50 & 2,1 & 2,2 & 1,0 \\
\hline Total & 3582 & 3049 & 533 & 7432 & 6513 & 919 & 2,1 & 2,1 & 1,7 \\
\hline
\end{tabular}




\section{Elka Dogramadjieva}

The studied villages attract also a significant number of day visitors who come for sightseeing but stay in other places in the region. According to the respondents they comprise the biggest share in the overall volume of demand ( $81 \%$ in Lesten, $70 \%$ in Dolen, $66 \%$ in Kovachevica). Thus, the annual number of day and overnight visitors comes up to nearly 13000 but less than $1 / 3$ of them spend at least one night in local establishments (Table 6).

Table 6. Total number and share of overnight and day visitors

\begin{tabular}{|l|r|r|r|r|r|r|r|r|r|}
\hline \multirow{2}{*}{} & \multicolumn{3}{|c|}{ Share of overnight visitors } & \multicolumn{2}{|c|}{ Share of day visitors } & \multicolumn{3}{|c|}{ Total number of visitors } \\
\cline { 2 - 10 } & Total & Domestic & Foreign & Total & Domestic & Foreign & Total & Domestic & Foreign \\
\hline Lesten & $19 \%$ & $20 \%$ & $10 \%$ & $81 \%$ & $80 \%$ & $90 \%$ & 4420 & 4030 & 390 \\
\hline Kovachevica & $33 \%$ & $31 \%$ & $49 \%$ & $67 \%$ & $69 \%$ & $51 \%$ & 6214 & 5298 & 916 \\
\hline Dolen & $30 \%$ & $30 \%$ & $30 \%$ & $70 \%$ & $70 \%$ & $70 \%$ & 2230 & 2067 & 163 \\
\hline Total & $28 \%$ & $27 \%$ & $36 \%$ & $72 \%$ & $73 \%$ & $64 \%$ & 12864 & 11394 & 1470 \\
\hline
\end{tabular}

Territorial distribution of tourist flows indicates different attractiveness, popularity and level of tourism development in the studied villages (Figure 5). Kovachevica occupies the leading position, especially with the reference to the international market - more than $80 \%$ of foreign overnight visitors and nights spent are concentrated there. Domestic demand is more evenly distributed but it is also directed mainly to Kovachevica. The rest of the villages are of much lower share in territorial distribution of demand although Lesten is a stopover for many visitors on their way to Kovachevica.

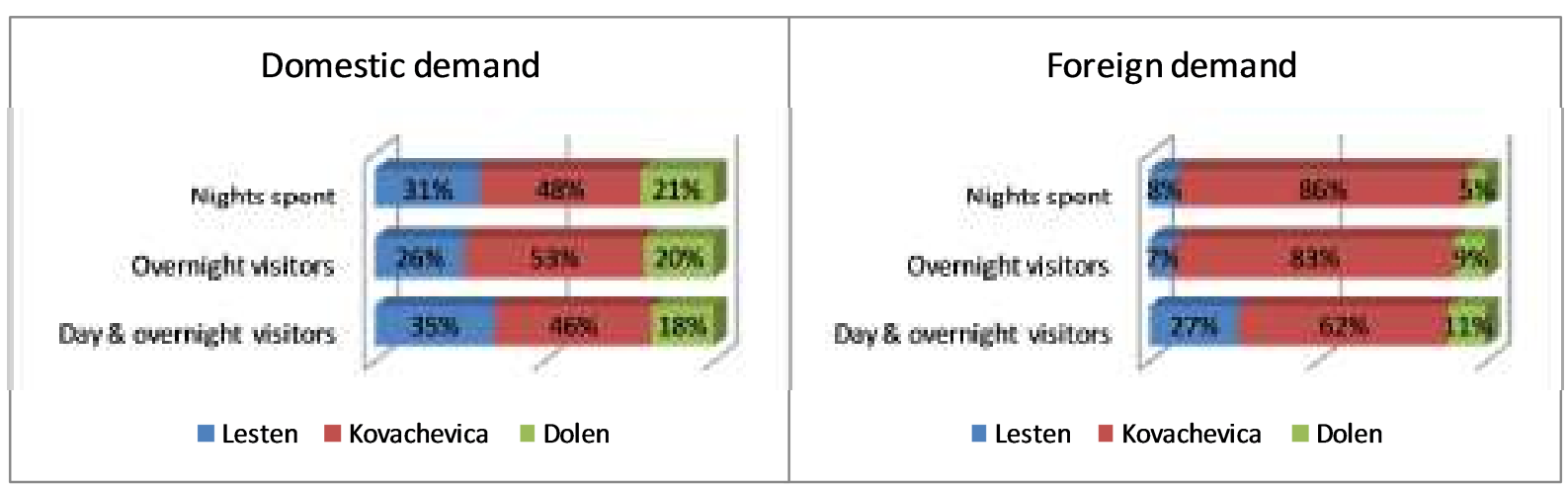

Figure 5. Territorial distribution of domestic and foreign tourist demand

The three villages strongly rely on domestic market - Bulgarians make up $85 \%$ of all overnight visits and nearly $90 \%$ of the nights spent (Figure 6). International demand is of relatively high value only in Kovachevica where foreigners compose $22 \%$ of all overnight visits and $20 \%$ of the nights spent. The share of foreign market in Lesten and Dolen is negligible (3-7\%).

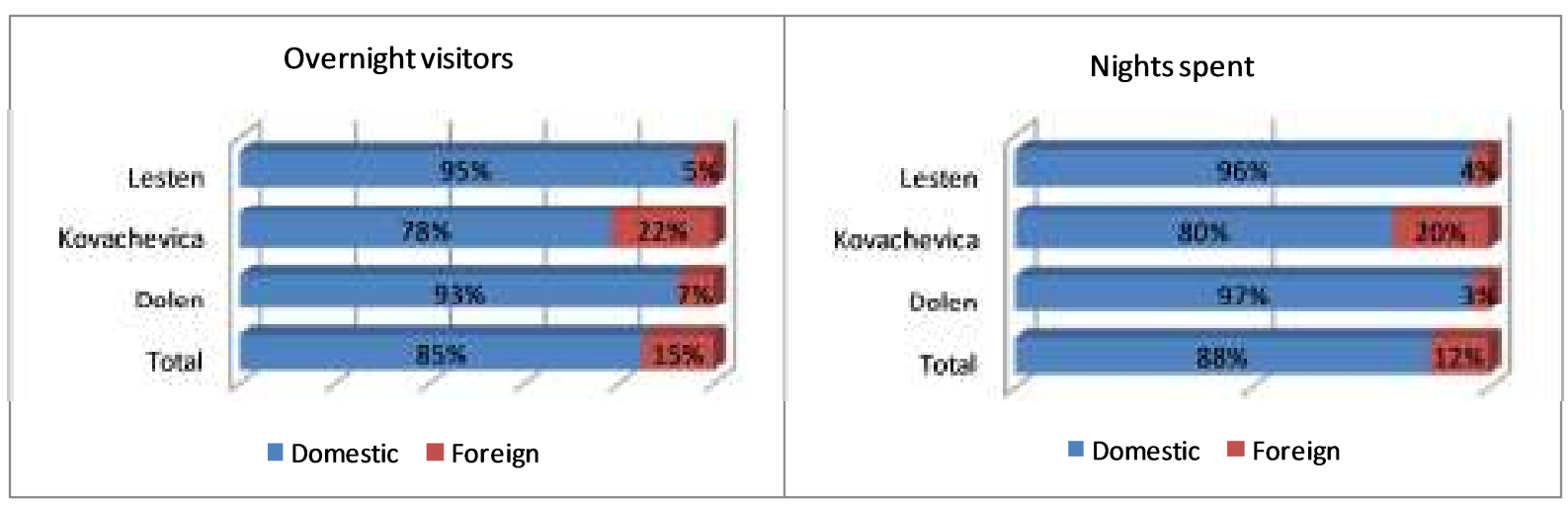

Figure 6. Share of domestic and international demand of accommodation facilities 


\subsection{Overnight visitors' profile and behavior}

The greatest majority of domestic tourists come from the capital city of Sofia. These visitors compose almost the whole domestic market of Lesten and $70-80 \%$ of it in Kovachevica and Dolen (Figure 7). Much more limited is the demand from other relatively close situated big cities like Plovdiv and Blagoevgrad (5-6\%). Visits from remote regions of the country (Varna, Burgas, Russe, etc.) are rather typical of Dolen.

Foreign market is strongly dominated by visitors from France and Britain who make up the entire demand of Lesten, nearly 70\% of it in Kovachevica and half of it in Dolen (Figure 7). Relatively diversified structure of foreign demand is found in Kovachevica which is visited also by German, American, Belgian and Dutch tourists. The small international market of Dolen comprises high share of Czech, Israel and Japanese tourists. Despite the proximity to the Greek border, the share of overnight visitors from Greece is quite small (just $6 \%$ of all foreigners in Kovachevica and 3\% of them in Dolen).

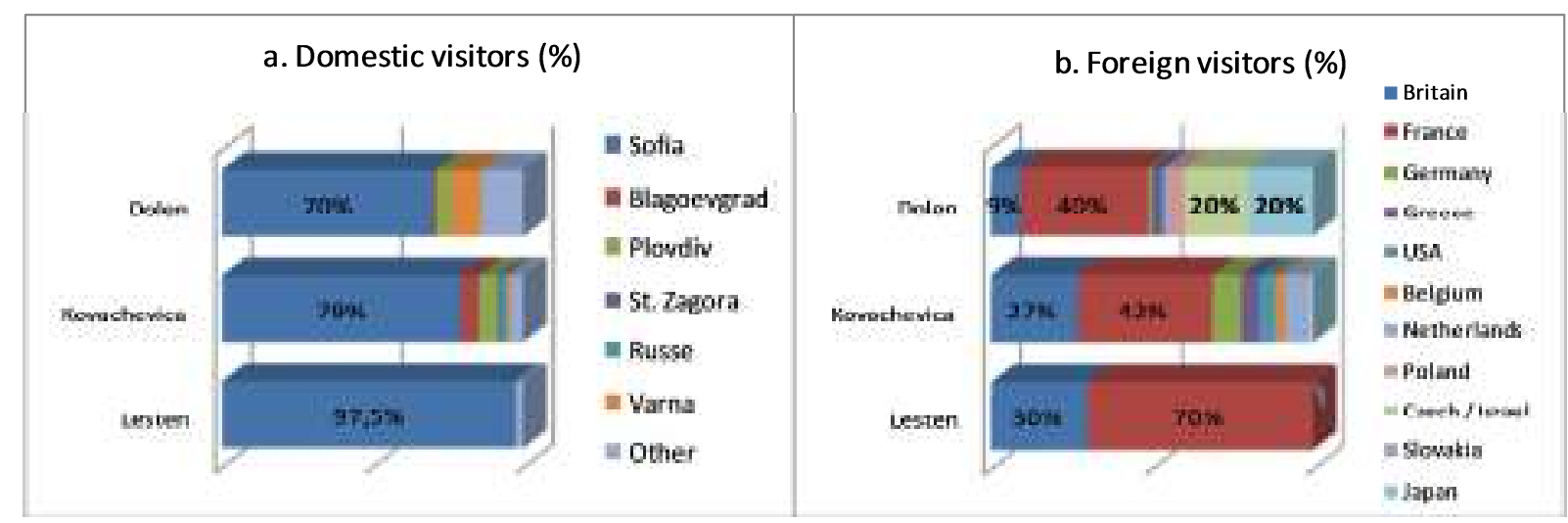

Figure 7. Origin of Bulgarian and foreign overnight visitors

Bulgarian tourists visit the area mainly for the weekend, while foreigners come exclusively within longer trips in the country. In this respect the three villages show similar structure of foreign demand but are quite different with the reference to domestic market features (Figure 8). Lesten is visited by Bulgarian overnight tourists only for the weekends and the official holidays. Weekend tourism is the dominating one in Kovachevica as well but some people stay there within a longer trip in the country $(8 \%)$ or come for mountain vacation (3\%); others combine their visit with sea recreation in Greece (4\%). Dolen attracts almost equal share of Bulgarian weekend visitors (49\%) and tourists for longer mountain vacation (40\%) as well as participants in tourism circuits (10\%). In regards to the international market, only Kovachevica is visited for weekend tourism - by foreigners who live in Bulgaria, not by Greek tourists. It is also worth mentioning that few of domestic and international tourists participate in cross-border trips, which indicates the lack of combined products offered in the area and no benefits obtained from the potential advantages of geographical location. 


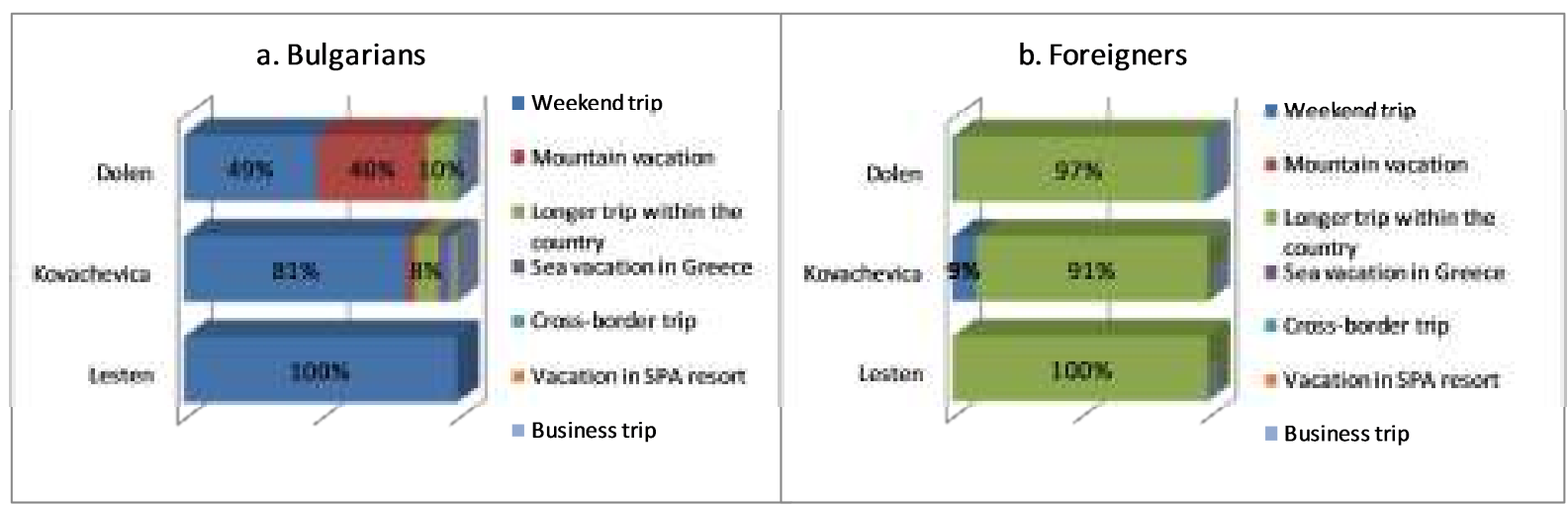

Figure 8. Structure of domestic and foreign demand by types of trips

The three villages show differences also with the reference to the type of organization of overnight tourists (Figure 9). Domestic market of Kovachevica and Dolen is strongly dominated by non-organized visitors (above 90\%) while in Lesten the both segments are almost equally presented (45:55). The real proportion in Lesten is even stronger in the favor of organized Bulgarian visitors as one of the two accommodation establishments there (which holds $80 \%$ of the available beds and $90 \%$ of the nights spent) strongly relies on intermediary tourism companies operating on domestic market as well as on corporate clients who come for team-building and other incentives.

International demand is almost entirely determined by organized tourists in Dolen (90\%) while in Kavachevica and Lesten non-organized foreign overnight visitors strongly prevail. The great share of individual foreigners is very untypical for Bulgarian tourism in general and it is explained by the fact that the two villages are well presented abroad and are quite popular as alternative tourism sites.

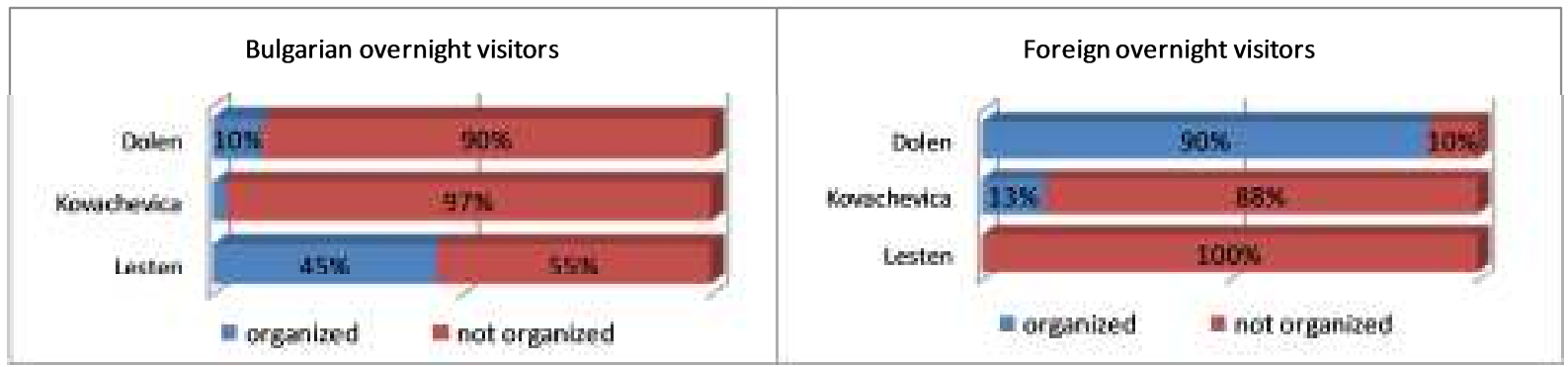

Figure 9. Organized and individual visitors (average of percentages indicated by the respondents)

Considerable share of domestic tourists are regular guests of the region while foreigners who make repeat visits are rather an exception. The indisputable leader in regards to the loyal customers is Kovachevica (Figure 10). Practically all accommodation establishments there attract repeat domestic visits. Moreover, $27 \%$ of the respondents have stated that these guests comprise $70 \%-90 \%$ of their entire clientele. In the rest of the cases the share of loyal customers is about $10 \%-20 \%$. Few of the houses are repeatedly visited by foreigners. Yet, one of the establishments is unique by the high share of its international repeat clients $(20 \%)$ and by the fact that some of the foreigners have visited it more than 50 times for a period of 15-16 years. Conversely, Lesten and Dolen are similar in the small share of loyal domestic customers $(10 \%)$ and in the lack of foreign repeat visits. This could be explained by the lower level of their tourism development but also by their weak tourism image. In contrast to Dolen and Lesten, Kovachevica has obtained the image of a place where one gets back - mainly due to irrational factors like prestige, fashion and elitism. 
Field Research of Tourism Supply and Demand in Mountain Villages:

The Case of West Rhodopes Architecture Reserves

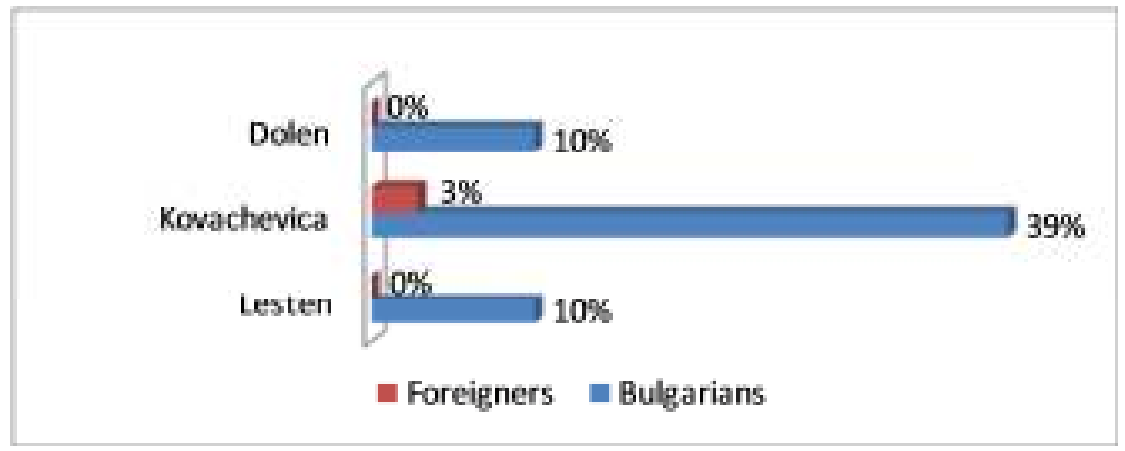

Figure 10. Share of loyal domestic and foreign clients by villages

\subsection{Seasonality of demand and utilization of accommodation facilities}

The three villages are characterized by high seasonality of tourist demand with a clearly outlined peak in the number of overnight visits and nights spent in July-August and much higher volume of demand during the warm half of the year. No distinct differences between domestic and foreign markets are identified in this regard (Figure 11). Yet, Bulgarian demand is activated not only in summer but also in April-May as well as during the winter holidays in December. International demand is concentrated from June to September $(80 \%$ of foreign overnight visits and $70 \%$ of the nights spent). The seasonality problem is most prominent in Dolen $-2 / 3$ of all nights spent there are concentrated within 3 months: August (35\%), December (18\%) and May (12\%) while six months of the year are off season (Figure 11). More evenly distributed within the year is the tourist demand in Kovachevica but even there the number of nights spent from April to October is 2,5 times greater than in the cold season and the volume of demand in August is 7 times bigger than in January or in February.

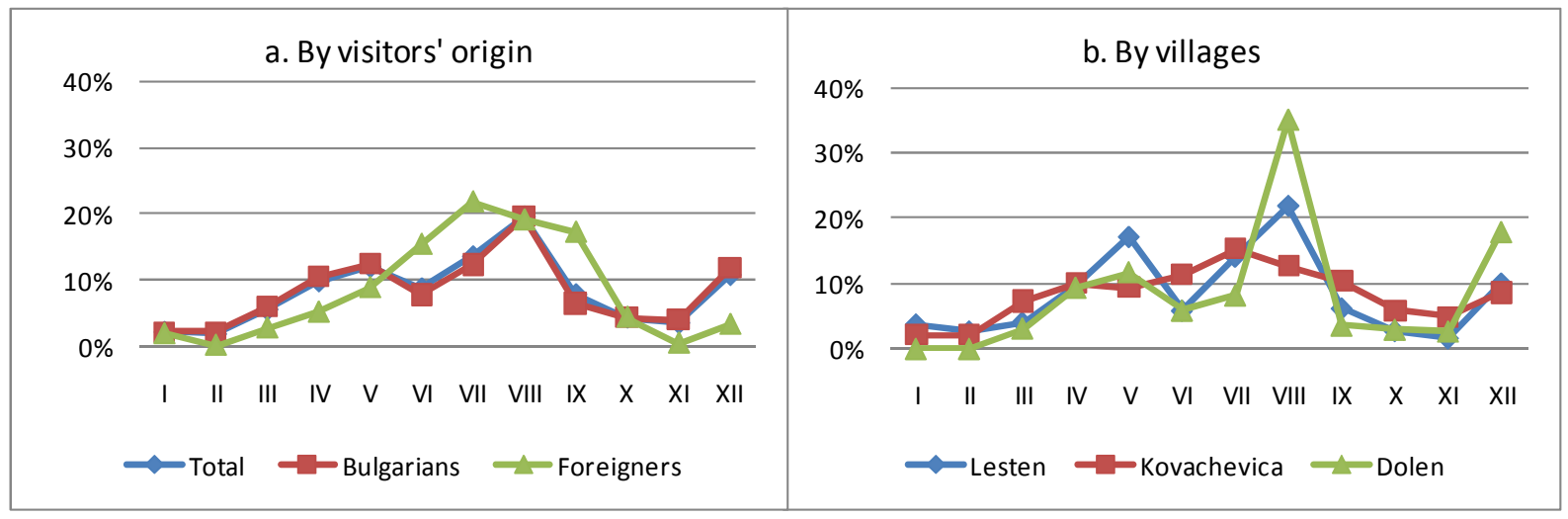

Figure 11. Seasonality in tourist demand by visitors' origin and by villages - share of nights spent

Duration of tourist stay is short throughout the year. No seasonal changes are observed in the stay of foreigners - all months they spend less than 2 nights in the studied villages. Bulgarians stay a bit longer during the Easter and Christmas holidays but even then not more than 2,5-3 nights are spent per visitor. In August the average duration of stay of domestic visitors is about 3 nights in Dolen and Lesten while at the same time in Kovachevica Bulgarians spend 1,5 nights as average. This indicates the differences among the villages with the reference to the type of tourism in the peak season predominantly short stationary vacations in Dolen and Lesten and weekend or circuit visiting tourism in Kovachevica. 
Survey results show extremely low occupancy rate of available bed places in 2010 - just $8 \%$ in Lesten and Kovachevica and 3\% in Dolen (Table 7). This is a crucial problem in all studied villages even though we assume that the respondents may have underrated the real number of nights spent in their establishments. Even if doubled or tripled, the annual occupancy rate would still be far below $30 \%$ which is considered acceptable in terms of effective utilization. The highest occupancy rates are achieved in July and August but even in the peak months not more than 15\%-20\% of the available bed capacity is utilized. Accommodation facilities are entirely full during the spring and winter holidays but for a few days only. Therefore, occupancy rates in April, May and December rarely exceed 10\%. The rest of the time the accommodation facilities are practically empty and almost half of the year the average occupancy rates in the three villages are around and below $5 \%$.

Table 7. Occupancy rates of available accommodation capacity in 2010 by months

\begin{tabular}{|l|r|r|r|r|r|r|r|r|r|r|r|r|r|}
\hline & I & II & III & IV & V & VI & VII & VIII & IX & X & XI & XII & Total \\
\hline Lesten & $4 \%$ & $3 \%$ & $4 \%$ & $9 \%$ & $16 \%$ & $6 \%$ & $13 \%$ & $21 \%$ & $6 \%$ & $3 \%$ & $2 \%$ & $9 \%$ & $8 \%$ \\
\hline Kovachevica & $2 \%$ & $2 \%$ & $7 \%$ & $10 \%$ & $9 \%$ & $11 \%$ & $15 \%$ & $12 \%$ & $10 \%$ & $6 \%$ & $5 \%$ & $8 \%$ & $8 \%$ \\
\hline Dolen & $0 \%$ & $0 \%$ & $1 \%$ & $4 \%$ & $5 \%$ & $2 \%$ & $3 \%$ & $14 \%$ & $1 \%$ & $1 \%$ & $1 \%$ & $7 \%$ & $3 \%$ \\
\hline Total & $2 \%$ & $2 \%$ & $4 \%$ & $8 \%$ & $9 \%$ & $7 \%$ & $10 \%$ & $15 \%$ & $6 \%$ & $3 \%$ & $3 \%$ & $8 \%$ & $6 \%$ \\
\hline
\end{tabular}

\subsection{Investments in individual product development and future business priorities}

Over the last five years entrepreneurs in the three studied villages have invested rather in capacity extension than in standard improvement (Figure 12). The number of bed places has been increased in $32 \%$ of the units while in $29 \%$ of the cases offered accommodation conditions have been upgraded. New amenities and services have been developed by only $14 \%$ of the respondents while $21 \%$ of them have made no investments at all. On the other hand, $25 \%$ of the establishments are entirely new and most of them provide better standard than the older ones. The high share of new investments illustrates the intensive growth of local business despite the current crisis but should be seen also as a challenge in terms of extremely low occupancy rates of the available capacity and stagnating tourist demand.

The three villages differ in regards to the investments made by local entrepreneurs (Figure 12). In Lesten one of the accommodation units is brand new but in the other one no investments have been made since it was opened in the mid 1990s. Improvement of accommodation standard and offering of new amenities and services are most widely spread in Kovachevica. Capacity extension is most typical of Dolen but over the last five years no investments have been made in $1 / 3$ of the establishments there.

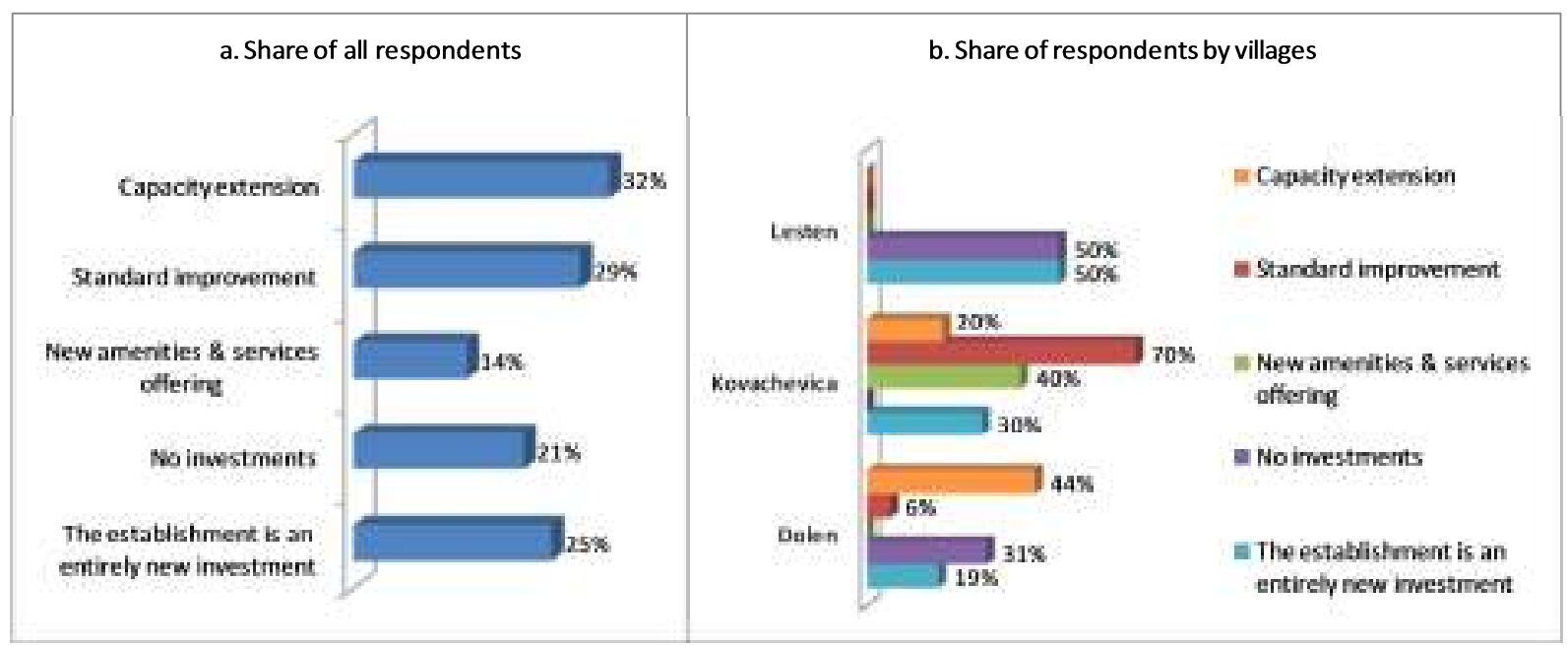

Figure 12. Types of investments in individual product development over the last five years (\% of respondents) 
Generally, respondents address rather quantitative than qualitative product and market development in their future business priorities (Table 8). Almost all of them are aimed on attracting new visitors. Nearly $70 \%$ would rely on a greater number of repeat visits but less than half - on lengthening the visitors' stay (which is obviously considered more unrealistic, especially in Kovachevica). Quality improvement and new investments are envisaged by $24 \%$ of all participants in the survey but high share of such intensions is observed mainly in Kovachevica. Nobody in the three villages is planning to raise the prices because of the limited solvency of potential tourists in the time of crisis. Despite the problematic utilization of accommodation facilities and the stagnating tourist market there are no intensions to close some of the establishments as in most of the cases receipts from tourism are additional income.

Table 8 . Future business priorities (\% of respondents)

\begin{tabular}{|c|c|c|c|c|c|c|c|c|}
\hline & 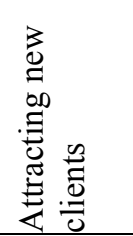 & 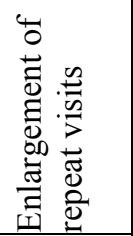 & 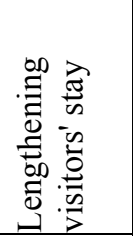 & 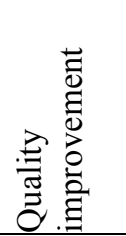 & 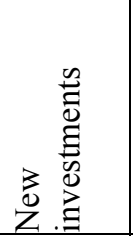 & 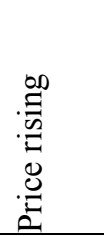 & 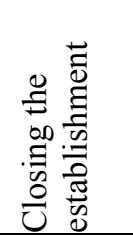 & 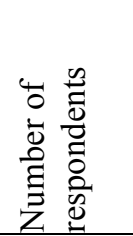 \\
\hline Lesten & $100 \%$ & $50 \%$ & $50 \%$ & $0 \%$ & $50 \%$ & $0 \%$ & $0 \%$ & 2 \\
\hline Kovachevica & $91 \%$ & $82 \%$ & $36 \%$ & $45 \%$ & $45 \%$ & $0 \%$ & $0 \%$ & 11 \\
\hline Dolen & $100 \%$ & $63 \%$ & $50 \%$ & $13 \%$ & $6 \%$ & $0 \%$ & $0 \%$ & 16 \\
\hline Total & $97 \%$ & $69 \%$ & $45 \%$ & $24 \%$ & $24 \%$ & $0 \%$ & $0 \%$ & 29 \\
\hline
\end{tabular}

\section{Conclusions}

The questionnaire-based survey of local entrepreneurs has provided a plenty of qualitative and quantitative information about the current state of tourism in the studied area. It should be stressed that no official recording of overnight visitors, nights spent or other data is conducted in the accommodation establishments in the three villages. Therefore, the presented figures regarding tourism supply and demand are tentative. Nonetheless, they fill in the information gap resulting from the small and fragmented local tourism business that falls beyond the scope of the official statistics as well as from the high share of uncategorized establishments that in fact operate illegally and do not exist in the registers of local administration.

The comparative analysis of the three villages has revealed a number of common features and problems regarding individual product development, marketing and utilization of the existing tourism potential and facilities. Essential distinctions have also been outlined and made it possible to identify different models of rural tourism development in mountain villages that are a subject of a separate publication (Assenova, 2012).

The research methodology is particularly appropriate for small destinations and could be applied in other mountain areas. However, the developed questionnaire showed to be too long. Its completion took about one hour per respondent, so it could be reduced in the future by removing some of the questions in conformity to the specific aims of the next surveys. Definitely the approach of interviewer-completion should be retained as this is the most efficient way to motivate the respondents to participate and to obtain significant information that otherwise entrepreneurs are reluctant to give. In this respect, the attendance of well trained and experienced interviewers in such surveys is of crucial importance. 


\section{Elka Dogramadjieva}

\section{References}

Assenova, M. 2010. Methodology for Monitoring Sustainable Tourism Development at Municipal Level. Annuaire de l'Universite de Sofia "St. Kliment Ohridski”, Faculte de Geologie et Geographie, Livre 2, Geographie, Tome 102, 2009. Sofia University Press, 227-252.

Assenova, M. 2012. Models of Rural Tourism Development in Mountain Villages. Book of Abstracts of the SEEmore Conference "Mountain Resources and their Response to Global Change", Ankara University, 5-8 July 2012.

Dogramadjieva, E. 2003. Concept for Sustainable Tourism Development in Teteven, Trojan and Apriltzi Municipalities (dissertation). Sofia University “St. Kliment Ohridski”, Sofia, Bulgaria.

Evrev, P., V. Marinov, M. Vodenska, M. Assenova, E. Dogramadjieva, St. Motev, S. Vasileva and M. Novakova. 2003. Concept for Territorial Development of Tourism in Bulgaria: Preliminary Analysis. National Center for Regional Development, Ministry of Regional Development and Public Works, Sofia, Bulgaria.

Gunn, C. A. 1988. Tourism Planning. New York, USA.

Inskeep, E. 1991. Tourism Planning: an Integrated and Sustainable Development Approach. New York, USA.

Marinov, V., N. Popova, M. Assenova and E. Dogramadjieva 2009. Tourism Regionalization of Bulgaria - between Political Needs and Theoretical Challenges. Proceedings of the International Conference "Global Changes: Vulnerability, Mitigation and Adaptation”, Sofia - Bulgaria, 17-18 April, 2008. Sofia University Press, 235-244.

Marinov, V. 2012. Key Informats' Analysis of Small Scale Tourism Development in Mountain Villages. Book of Abstracts of the SEEmore Conference "Mountain Resources and their Response to Global Change", Ankara University, 5-8 July 2012.

Marinov, V. 2004. Current state and dynamics in tourism development in Bulgaria by planning regions and administrative districts. Geogrraphy... Yesterday, Today and Tomorrow. Sofia University Press, 218-232.

Marinov, V., V. Janeva, M. Vujarova and R. Minkovski. 2000. Monitoring of Tourist Demand. Regional Information System for Monitoring of Tourist Demand in Pirin Tourist Region. Sofia University Press, Sofia, Bulgaria.

Middleton, V. and R. Hawkins. 1998. Sustainable Tourism: A Marketing Perspective. Oxford, UK.

Popova, N., M. Vodenska, E. Dogramadjieva, M. Assenova and P. Slaveykov. 2005. Tourism Baseline Survey in Kazanluk Municipality. JICA, Sofia, Bulgaria.

Vodenska, M. 2001. Economic, Social and Environmental Impacts of Tourism. Sofia University Press, Sofia, Bulgaria.

Vodenska, M. 2005. Tourism Impacts Assessment in Bulgaria. Avangard Prima Press, Sofia, Bulgaria. 